\title{
The Value of Computerised Tomography in Diagnosis and Management of COVID-19 Associated Pulmonary Aspergillosis
}

\section{COVID-19 Ilișkili Pulmoner Aspergilloz Tanı ve Yönetiminde Bilgisayarlı Tomografinin Önemi}

Elif Mukime SARICAOG̃LU'(İD), Adalet AYPAK²(ID), Murathan KÖKSAL ${ }^{3}(\mathrm{ID})$, Esragül AKINCl2(IID)

\footnotetext{
${ }^{1}$ Department of Infectious Diseases and Clinical Microbiology, Ankara University Faculty of Medicine, Ankara, Turkey

${ }^{2}$ Department of Infectious Diseases and Clinical Microbiology, University of Health Sciences Ankara City Hospital, Ankara, Turkey

${ }^{3}$ Clinic of Radiology, University of Health Sciences Ankara City Hospital, Ankara, Turkey
}

Cite this article as: Sarıcaoğlu EM, Aypak A, Köksal M, Akıncı E. The value of computerised tomography in diagnosis and management of COVID-19 associated pulmonary aspergillosis. FLORA 2021;26(3):556-9.

\begin{abstract}
Patients with coronavirus disease 2019 (COVID-19) might be at risk for pulmonary aspergillosis. The role of computerised tomography in early diagnosis, prediction of disease severity and managing of COVID-19 patients is critical. Herein, we presented pulmonary aspergillosis in a COVID-19 patient diagnosed and followed-up with computerised tomography imaging.
\end{abstract}

Key Words: Coronavirus disease 2019; Pulmonary aspergillosis; Computerised tomography

ÖZ

COVID-19 Ilișkili Pulmoner Aspergilloz Tanı ve Yönetiminde Bilgisayarlı Tomografinin Önemi

Elif Mukime SARICAOG̃LU', Adalet AYPAK², Murathan KÖKSAL ${ }^{3}$, Esragül AKINCl ${ }^{2}$

\footnotetext{
${ }^{1}$ Ankara Üniversitesi Tıp Fakültesi, İnfeksiyon Hastalıkları ve Klinik Mikrobiyoloji Anabilim Dalı, Ankara, Türkiye

2 Sag̃ılk Bilimleri Üniversitesi Ankara Șehir Hastanesi, İnfeksiyon Hastalıkları ve Klinik Mikrobiyoloji Klinig̃i, Ankara, Türkiye

${ }^{3}$ Sag̃ılık Bilimleri Üniversitesi Ankara Șehir Hastanesi, Radyoloji Klinig̃i, Ankara, Türkiye
}

Koronavirüs hastalığı 2019 (COVID-19) olan hastalar, pulmoner aspergilloz açısından riskli olabilirler. Bilgisayarlı tomografinin erken tanı, hastalık şiddetinin öngörülmesi ve COVID-19 hastalarının yönetimindeki rolü kritiktir. Burada bir COVID-19 hastasında gelişen bilgisayarlı tomografi görüntülemeleri ile tanı koyulan ve takip edilen pulmoner aspergilloz sunmaktayız.

Anahtar Kelimeler: Coronavirüs hastalığı 2019; Pulmoner aspergilloz; Bilgisayarlı tomografi 


\section{INTRODUCTION}

Since the first recognition in December 2019 , millions of people have been infected with the severe acute respiratory syndrome coronavirus 2 (SARS-CoV-2) and hundreds of thousands people have died because of COVID-19[1]. Especially, increase in life saving dexamethasone and anti-interleukin 6-directed treatments in severe patients could lead to increment in susceptibility to superinfection including aspergillosis ${ }^{[2]}$. Diagnosis of COVID-19-associated Pulmonary Aspergillosis (CAPA) which requires histopathological findings and culture remains difficult and even underdiagnosed ${ }^{[3]}$. The role of computerized tomography (CT) in early diagnosis, prediction of disease severity and managing of COVID-19 patients was described in previous publications ${ }^{[4]}$. In this study, we reported pulmonary aspergillosis in a COVID-19 patient diagnosed and followed-up with $\mathrm{CT}$ imaging.

\section{Case Description}

Here, we report a 50-year-old male who was diagnosed with COVID-19. Underlying disease included hypertension and operated atrial septal defect. He has been working in the field of air conditioning and cooling systems. Laboratory and CT findings (Figure 1a) and oxygen saturation was normal. Initial favipiravir treatment for $\mathrm{CO}$ VID-19 was supervised at home according to current guideline of Turkish Ministry of Health Scientific Committee on COVID-19.

The patient applied to the emergency department because of cough, dyspnea, tachypnea and continuation of fever on $4^{\text {th }}$ day of illness. White blood cell count was $18.87 \times 10^{9} / \mathrm{L}$, lymphocyte count $0.76 \times 10^{9} / \mathrm{L}$. Liver function tests demonstrated aspartate aminotransferase (AST) $41 \mathrm{U} / \mathrm{L}$, alanine aminotransferase (ALT) $40 \mathrm{U} / \mathrm{L}$, and lactate dehydrogenase (LDH) $707 \mathrm{U} / \mathrm{L}$. Renal function was normal. Coagulation parameters revealed that d-dimer was $3.8 \mathrm{mg} / \mathrm{L}$ and fibrinogen $7.68 \mathrm{~g} / \mathrm{L}$. Methylprednisolone and enoxaparin sodium were prescribed. The patient was admitted to intensive care unit (ICU) because of hypoxemia (oxygen saturation $87.5 \%$ on room air) and clinical deterioration on $6^{\text {th }}$ day of illness. He followed-up with high flow nasal cannula initially, but oxygen support was switched to non-invasive mechanical ventilation because of respiratory deterioration on the $15^{\text {th }}$ day of admission to ICU. Respiratory tract specimens were obtained by non-bronchoscopic endotracheal aspirate (ETA) and piperacillin/ tazobactam was initiated. Antibacterial treatment was terminated on $7^{\text {th }}$ day because of lack of microbiological documentation.

On day $25^{\text {th }}$ of admission to the ICU, worsening respiratory function and hypercapnia were observed. No clinical signs of heart failure were detected. A trans-thoracic echocardiogram was performed and demonstrated normal biventricular function with $60 \%$ ejection fraction and no vegetation. Pulmonary CT angiography imaging excluded pulmonary embolism revealed that thick-walled cavitary lesion $(62.5 \times 35 \mathrm{~mm})$ which contained soft tissue localized in the superior segment in the lower lobe of the left lung and bilaterally groundglass opacities with low density (Figure 1b-d). We couldn't perform bronchoscopy for differential diagnosis because it is an aerosol-generating procedure that poses transmission risk and could cause worsening respiratory functions of patient. ETA testing was repeated. Fungal cultures, Ehrlich-Ziehl Neelsen (EZN) staining, Mycobacterium tuberculosis Polymerase Chain Reaction (PCR) and galactomannan (GM) testing of respiratory specimen and galactomannan in serum were negative. We started liposomal amphotericin B (3 mg/kg/day) for pulmonary aspergillosis with high clinical suspicion and supported typical radiological findings. Surgical management could not be performed because the lesion's anatomical localization was close to the vascular structure and hemodynamic instability of patient. Rapid improvement in clinical and respiratory function of patient was observed following 5 days after antifungal treatment. The patient did not need oxygen support on the $8^{\text {th }}$ day of antifungal treatment. We switched the antifungal treatment to voriconazole $(2 \times 6 \mathrm{mg} / \mathrm{kg}$ induction, $2 \times 4 \mathrm{mg} / \mathrm{kg}$ maintenance), and the patient was discharged from hospital with oral voriconazole and has recovered well at home. Control CT-scan at second month of antifungal treatment showed that significant reduction in cavitary lesion's dimension $(36 \times 21 \mathrm{~mm})$ (Figures 1e-f). Voriconazole was stopped with complete improvement in the cavitary lesion after five months of antifungal therapy (Figures 1g-h). 


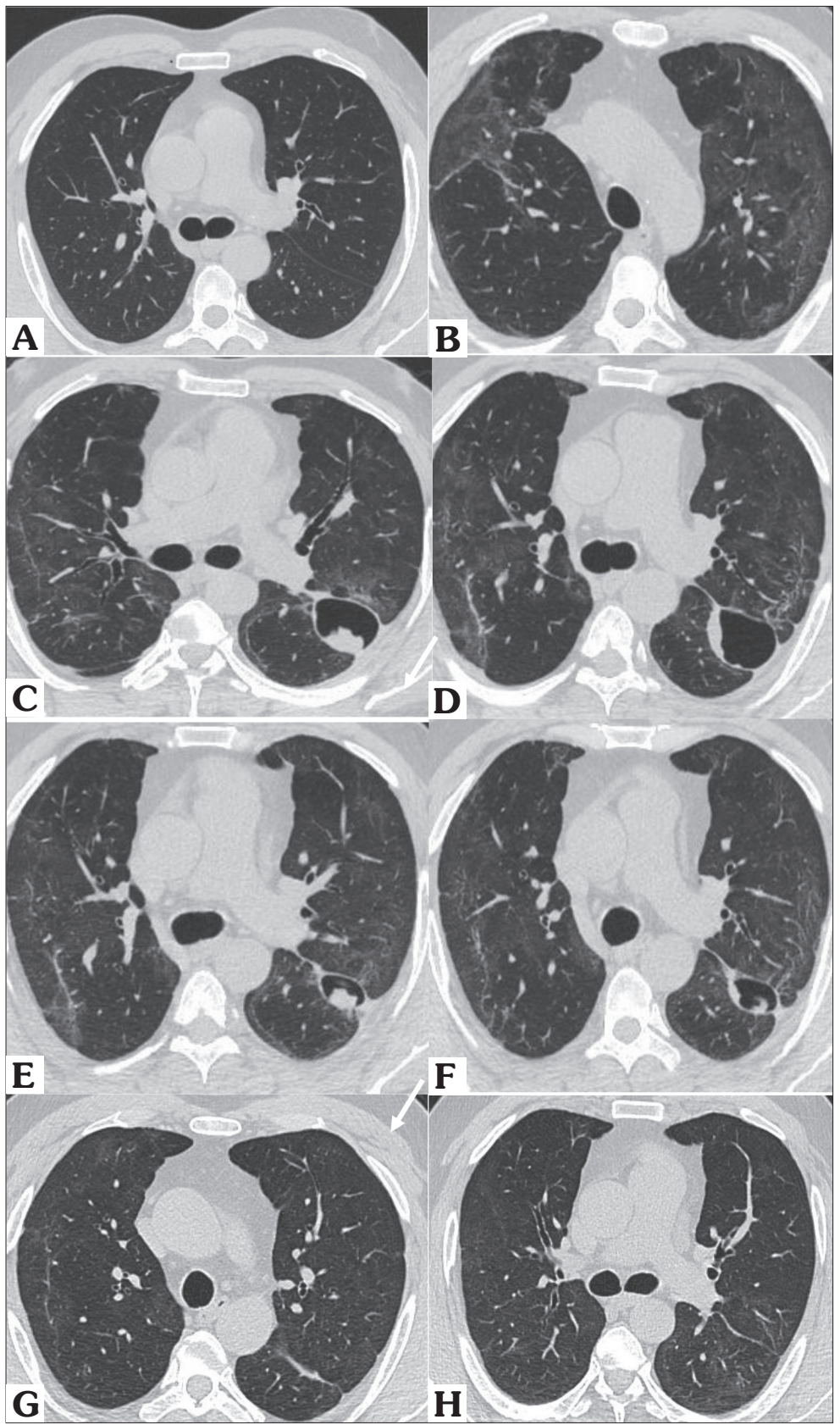

Figure 1. Dynamic changes on computerised tomography findings during management of COVID-19 patient with pulmonary aspergillosis; 1a) Radiological findings of SARS-CoV2 infection at the time of diagnosis $1 \mathrm{~b}-\mathrm{d}$ ) Radiological findings of post SARS-CoV2 infection with pulmonary aspergillosis 1e-f) Radiological findings at second month of antifungal treatment. $1 \mathrm{~g}$-h) Radiological findings at fifth month of antifungal treatment. 1a) Normal lung parenchyma; 1b) Bilateral predominantly peripheral ground-glass opacities with low density and fibroatelectatic irregular reticulation in the right lobe of lung in accordance with post COVID-19; 1c) thick-walled cavitary lesion $(62.5 * 35 \mathrm{~mm})$ which contains nodular opacity localized in the superior segment of the lower lobe of the left lung $1 \mathrm{~d})$ appearance of cavitary lesion $\left(47^{*} 37 \mathrm{~mm}\right)$ at lower level section $\left.1 \mathrm{e}-\mathrm{f}\right)$ Improvement in ground-glass opacities and regression in cavitary lesion's size and nodular opacity at second month of antifungal treatment $1 \mathrm{~g}-\mathrm{h}$ ) Completely improvement in cavitary lesion at the end of antifungal treatment. 


\section{DISCUSSION}

The purpose of this case report was to describe the imaging and associated clinical features of a COVID-19 patient with pulmonary aspergillosis. There is raising concerns about patients with $\mathrm{CO}$ VID-19 might be at risk for invasive pulmonary aspergillosis ${ }^{[5]}$. Koehler et al. have published consensus definitions based on clinical, radiological and mycological criteria for $\mathrm{CAPA}^{[2]}$. But consensus definitions for CAPA are mainly for researchers to classify patients in registries and clinical trials ${ }^{[2]}$. Here, the patient could not be classified according to this scheme, because we could not obtain any positive microbiological result for Aspergillosis. Under the pandemic circumstances, microbiological testing and/or radiological examination can be restricted because of limited resources, clinical instability of patients and transmission risk, so these definitions cannot be applied sometimes in daily practice for managing patients with pulmonary aspergillosis (PA). High possibility of the patient's occupational exposure to Aspergillosis, typical radiological findings related with Aspergillosis, clinical and radiological improvement after antifungal treatment supported the diagnosis of Aspergillosis.

Chest CT had only 3.9\% missed COVID-19 diagnosis $^{[6]}$. The role of CT in early diagnosis, prediction of disease severity and managing of COVID-19 patients was described in previous publications $^{[4]}$. The presence of classical invasive aspergillosis findings such as cavitation on CT can help support the diagnosis and reduce the burden of evidence placed on mycological examinations in COVID-19 patients $^{[7]}$.

Clinicians should bear in mind fungal complications in addition to cardiac and thromboembolic events anytime worsening respiratory function in COVID-19 patients because early diagnosis and appropriate antifungal treatment initiation is the most important factor in reducing morbidity and mortality in PA. Radiology, especially, CT plays a critical role in recognizing and managing of patients with PA. We think that in the absence of clear diagnostic criteria, antifungal treatment should be considered if aspergillosis is suspected with clinically and radiologically in severe COVID-19 patients.

\section{CONFLICT of INTEREST}

No conflict of interest declared.

\section{AUTHORSHIP CONTRIBUTIONS}

Concept/Design: EMS, AA, EA

Analysis: EMS, AA, EA, MK

Data Acquisition: EMS, AA, EA, MK

Writting: EMS, AA, EA, MK

Revision and Correction: EMS, AA

Final Approval: EMS, AA

\section{REFERENCES}

1. Koeckerling D, Pan D, Barker J. Re: 'Efficacy and safety of tocilizumab in COVID-19 patients: A living systematic review and meta-analysis' by Tleyjeh et al. Clinical microbiology and infection: the official publication of the European Society of Clinical Microbiology and Infectious Diseases 2021.

2. Koehler P, Bassetti M, Chakrabarti A, Chen SC, Colombo AL, Hoenigl $M$, et al. Defining and managing COVID-19-associated pulmonary aspergillosis: the 2020 ECMM/ISHAM consensus criteria for research and clinical guidance. Lancet Inf Dis 2020.

3. Benedetti MF, Alava KH, Sagardia J, Cadena RC, Laplume D, Capece P, et al. COVID-19 associated pulmonary aspergillosis in ICU patients: Report of five cases from Argentina. Med Mycol Case Rep 2020;3124-8.

4. Al-Smadi AS, Bhatnagar A, Ali R, Lewis N, Johnson S. Correlation of chest radiography findings with the severity and progression of COVID-19 pneumonia. Clinical Imaging 2020;71:17-23.

5. Verweij $P E$, Gangneux J-P, Bassetti $M$, Brüggemann RJ, Cornely OA, Koehler $P$, et al. Diagnosing COVID-19-associated pulmonary aspergillosis. The Lancet Microbe 2020;1(2):e53-e5.

6. Li Y, Xia L. Coronavirus disease 2019 (COVID-19): role of chest CT in diagnosis and management. Am J Roentgenol 2020;214(6):1280-6.

7. Armstrong-James $D$, Youngs J, Bicanic T, Abdolrasouli A, Denning DW, Johnson $E$, et al. Confronting and mitigating the risk of COVID-19 associated pulmonary aspergillosis. Eur Respiratory Soc;2020;56(4):2002554.

8. Prasad A, Agarwal K, Deepak D, Atwal SS. Pulmonary aspergillosis: what CT can offer before it is too late! Journal of clinical and diagnostic research: JCDR 2016;10(4):TE01.

9. Li Y, Xia L. Coronavirus disease 2019 (COVID-19): role of chest $C T$ in diagnosis and management. Am J Roentgenol 2020;214(6):1280-6.

Address for Correspondence/Yazıșma Adresi

Dr. Elif Mukime SARICAOĞLU

Ankara U̇niversitesi Tıp Fakültesi,

İnfeksiyon Hastalıkları ve

Klinik Mikrobiyoloji Anabilim Dalı,

Ankara-Türkiye

E-mail: elifmozturk@gmail.com 